\title{
ASPECTS OF THE ECOLOGY OF PROTEOCEPHALID CESTODES PARASITES OF Sorubim lima (PIMELODIDAE) OF THE UPPER PARANÁ RIVER, BRAZIL: I. STRUCTURE AND INFLUENCE OF HOST'S SIZE AND SEX
}

\author{
TAKEMOTO, R. M. and PAVANELLI, G. C. \\ Universidade Estadual de Maringá, DBI/Nupélia-PEA, Bloco G-90, Av. Colombo, 5790, CEP 87020-900, Maringá, \\ PR, Brazil \\ Correspondence to: Ricardo Massato Takemoto, Universidade Estadual de Maringá, Nupélia, Bloco G-90, Av. \\ Colombo, 5790, CEP 87020-900, Maringá, PR, Brazil, e-mail: takemotorm@nupelia.uem.br \\ Received June 28, 1999 - Accepted January 12, 2000 - Distributed November 30, 2000
}

\begin{abstract}
Between March 1992 and February 1996, 107 specimens of Sorubim lima were collected in the floodplain of the upper Paraná river. Ninety-five $(88.78 \%)$ specimens were parasitized with at least one species of proteocephalid cestodes. 7,573 specimens of four different species were collected (average intensity 79.71 parasites/host): Paramonticellia itaipuensis Pavanelli \& Rego, 1991; Nupelia portoriquensis Pavanelli \& Rego, 1991; Spatulifer maringaensis Pavanelli \& Rego, 1989 and Spasskyellina spinulifera Woodland, 1935. S. maringaensis was the most prevalent and abundant. There were three dominant species $P$. itaipuensis, $S$. maringaensis and $N$. portoriquensis) and one co-dominant species ( $S$. spinulifera). The three environments (lotic, semilotic and lentic) in which collection was undertaken showed high similarity with regard to parasitic fauna. A high Simpson index value (0.359) indicates dominance tendency among species of parasites. Concerning $S$. maringaensis significant positive correlation was observed between parasite intensity and standard length of hosts. No species had negative correlation. With regard to $S$. maringaensis and $N$. portoriquensis prevalence was positive and significantly correlated with standard length of hosts. No species had negative correlation. In the case of $S$. maringaensis and $N$. portoriquensis influence of host's sex was noted on parasite intensity. There was no sex influence on parasite prevalence in any species.
\end{abstract}

Key words: ecology, community structure, size and sex influence, Sorubim lima, Proteocephalids, upper Paraná river, Brazil.

\section{RESUMO \\ Aspectos da ecologia de cestóides proteocefalídeos parasitas de Sorubim lima (Pimelodidae) do Alto Rio Paraná, Brasil: I. Estrutura e influência do tamanho e sexo dos hospedeiros}

No período de março de 1992 a fevereiro de 1996 foram coletados 107 espécimes de Sorubim lima na planície de inundação do alto rio Paraná, sendo que $95(88,78 \%)$ estavam parasitados por pelo menos uma espécie de cestóide proteocefalídeo. Foi coletado um total de 7.573 espécimes de parasitos (intensidade média de 79,71 parasitos/hospedeiro) de quatro espécies diferentes: Paramonticellia itaipuensis Pavanelli \& Rego, 1991; Nupelia portoriquensis Pavanelli \& Rego, 1991; Spatulifer maringaensis Pavanelli \& Rego, 1989 e Spasskyellina spinulifera (Woodland, 1935). Destas, S. maringaensis foi a de maior prevalência e a de maior abundância. Ocorreram três espécies dominantes (P. itaipuensis, $S$. maringaensis e $N$. portoriquensis) e uma espécie co-dominante ( $S$. spinulifera). Os três ambientes de coletas (lótico, semilótico e lêntico) apresentaram uma alta similaridade em relação à fauna parasitária. O alto valor obtido do índice de Simpson $(0,359)$ indica uma tendência para dominância entre as espécies de parasitos. Para Spatulifer maringaensis, observou-se correlação positiva signi- 
ficativa entre a intensidade de parasitismo e o comprimento-padrão dos hospedeiros, sendo que para nenhuma espécie a correlação foi negativa. Para S. maringaensis e $N$. portoriquensis, a prevalência apresentou-se positiva e significativamente correlacionada com o comprimento padrão dos hospedeiros. Para espécie alguma a correlação foi negativa. Para S. maringaensis e N. portoriquensis observou-se influência do sexo do hospedeiro sobre a intensidade parasitária, entretanto, não se constatou influência do sexo sobre a prevalência de parasitismo para espécie alguma.

Palavras-chave: ecologia, estrutura da comunidade, influência do tamanho e sexo, Sorubim lima, Proteocefalídeos, alto rio Paraná, Brasil.

\section{INTRODUCTION}

Studies on the ecology of parasite helminthes of fish are scanty, especially concerning regions with periodical floods. Many research works deal with taxonomic aspects of one species or group of parasites. Studies on the influence of biotic and abiotic factors on parasitic fauna are rare. Identical position may be stated with regard to changes caused by human activities in a determined fish population and its parasites. Research by Takemoto \& Pavanelli (1994), Machado et al. (1994, 1995, 1996) and Pavanelli et al. (1997) on ecology has been concentrated in the region in which the present research was developed. It presents the structure of a community of parasite cestodes in Sorubim lima (Bloch \& Schneider, 1801) and the influence of size and sex of hosts on the community.

\section{MATERIALS AND METHODS}

Collection of specimens of Sorubim lima was undertaken monthly in the floodplain of the upper Paraná river $\left(22^{\circ} 40^{\prime}-22^{\circ} 50^{\prime} \mathrm{S}\right.$ and $\left.53^{\circ} 15^{\prime}-53^{\circ} 40^{\prime} \mathrm{W}\right)$ during the period comprising March 1992 and January 1994, followed at random till February 1996. Simple stationary nets with mesh sizes 3 to $16 \mathrm{~cm}$ between opposite knots, stationary trammel nets with six and eight mesh, and boulters were used for the capture of fish. Collection, preparation and mounting of cestodes were undertaken according to techniques developed by Amato et al. (1991).

The following statistical tests and ecological indexes were used for data analyses: MannWhitney's U test with normal approximation Z for the evaluation of effect of host's sex on infection intensity for each parasite species (Siegel, 1975); test G Log-likelihood with contingency table 2 x 2 to estimate the effect of host's sex on the prevalence of each species of parasite (Zar, 1996);
Pearson's coefficient of linear correlation " $r$ " to determine the correlation between infection prevalence and standard length of host with previous angular transformation $(\operatorname{arcsen} \sqrt{x}$ ) of prevalence data and grouping of standard length of hosts at class intervals (Zar, 1996); Spearman's rank correlation coefficient "rs" to determine possible correlation between infection intensity and standard length of host. Above-mentioned tests were only applied for parasite species with prevalence higher than 10\% (Bush et al., 1990).

Importance value suggested by Bush (I) was used to characterize the importance of each species in the parasite community (Thul et al., 1985). Simpson index "C" was calculated to determine dominance tendency among parasite species. Dominance tendency was assumed when $\mathrm{C}>0.25$ (Stone $\&$ Pence, 1978; Yanez \& Canaris, 1988).

Similarity among parasite species in the three environments studied (lotic, semilotic and lentic) was determined by Sorenson's similarity index (Neraasen \& Holmes, 1975; Stone \& Pence, 1978). Terminology related to parasite ecology was based on Margolis et al. (1982) modified by Bush et al. (1997).

\section{RESULTS}

\section{Distribution of species of proteocephalids in host samples}

One hundred and seven specimens of Sorubim lima were analyzed. Ninety-five (88.78\%) were parasitized by at least one species of proteocephalid cestodes. A total of 7,573 parasite specimens were collected (average intensity of 79.72) belonging to four species: Paramonticellia itaipuensis Pavanelli \& Rego, 1991; Nupelia portoriquensis Pavanelli \& Rego, 1991; Spatulifer maringaensis Pavanelli \& Rego, 1989 and Spasskyellina spinulifera (Woodland, 1935). Cestode S. maringaensis was the most prevalent and the most abundant (Table 1). 
TABLE 1

Prevalence (P\%), mean intensity of infection (MII), range of variation (Rx), of 107 specimens of Sorubim lima collected, from March 1992 through February 1996 in the floodplain of the upper Paraná River, Brazil.

\begin{tabular}{|l|c|c|c|}
\hline \multicolumn{1}{|c|}{ Parasite } & P\% & MII & Rx \\
\hline Spatulifer maringaensis & 85.05 & 76.06 & $1-1613$ \\
\hline Paramonticellia itaipuensis & 73.83 & 4.53 & $1-16$ \\
\hline Nupelia portoriquensis & 28.97 & 8.74 & $1-94$ \\
\hline Spasskyellina spinulifera & 6.54 & 3.14 & $1-11$ \\
\hline
\end{tabular}

Some specimens of nematodes in the larval phase were also collected but could not be identified at species level. Intensity and prevalence were very low.

\section{Structure of the infracommunity of proteocephalid cestodes}

According to Bush importance value (Thul et al., 1985), the structure of the community of proteocephalid cestodes, parasites of Sorubim lima, exhibited three dominant species $(P$. itaipuensis, $S$. maringaensis and $N$. portoriquensis) and one co-dominant species ( $S$. spinulifera) (Table 2).

Fauna of proteocephalid cestodes of three collection environments (lotic, semilotic and lentic) had high similarities with regard to composition, according to Sorenson's index (Table 3). Cestode Spasskyellina spinulifera was not found in lentic environment.

TABLE 2

Classification and Bush's Importance values (I) of proteocephalid cestodes, parasites of Sorubim lima, collected from March 1992 to February 1996 in the floodplain of the upper Paraná River, Brazil.

\begin{tabular}{|l|c|}
\hline \multicolumn{1}{|c|}{ Parasite } & (I) \\
\hline \multicolumn{1}{|c|}{ Dominant Species } & 94.47 \\
\hline Spatulifer maringaensis & 4.24 \\
\hline Paramonticellia itaipuensis & 1.26 \\
\hline Nupelia portoriquensis Dominant Species & \\
\hline \multicolumn{1}{|c|}{ Co-Dasskellina spinulifera } & 0.023 \\
\hline
\end{tabular}

TABLE 3

Values of Sorensen's similarity coefficient for comparison of proteocephalid fauna of Sorubim lima in lotic, semilotic and lentic environments collected from March 1992 to February 1996 in the floodplain of the upper Paraná River, Brazil.

\begin{tabular}{|l|c|c|c|}
\hline & Lentic & Semilotic & Lotic \\
\hline Lentic & -------- & 85.71 & 85.71 \\
\hline Semilotic & & - & 100 \\
\hline Lotic & & & -------- \\
\hline
\end{tabular}


The infracommunity of parasite proteocephalids of Sorubim lima of the floodplain registered 0.346 for Simpson index, determining possible concentration to dominance among species of parasites.

Influence of host's standard length and sex in the infracommunity of proteocephalid cestodes

Size of sampled fish varied from 14.5 to $45.7 \mathrm{~cm}$ in standard length and 53.5 to $883.2 \mathrm{~g}$ in total weight.

According to Spearman rank correlation coefficient "rs", only the species Spatulifer maringaensis showed significant positive correlation between intensity of parasitism and standard length of hosts (Table 4). No negative correlation was detected in any species.

Linear correlation coefficient of Pearson " $\mathrm{r}$ " showed that prevalence for $S$. maringaensis and $N$. portoriquensis was positive and significantly correlated with the standard length of hosts (Table 4). No negative correlation was detected in any species.

Among species of cestodes with prevalence higher than $10 \%$ N. portoriquensis and S. maringaensis had some influence of host's sex on parasite intensity. Male hosts had a significantly higher parasite intensity than females. There was no influence of sex on the prevalence of parasitism (Table 5).

TABLE 4

Values of Spearman's rank correlation coefficient (rs) and Pearson's linear correlation coefficient (r) to evaluate correlation between standard length of Sorubim lima and the abundance and prevalence of preoteocephalids collected from March 1992 to February 1996 in the floodplain of the Paraná River, Brazil. ( $\mathbf{P}=$ significance level.)

\begin{tabular}{|l|c|c|c|c|}
\hline \multicolumn{1}{|c|}{ Parasite } & "rs" & P & "r" & P \\
\hline Paramonticellia itaipuensis & $0.066^{\mathrm{NS}}$ & $0.20<\mathrm{P}<0.50$ & $0.126^{\mathrm{NS}}$ & $\mathrm{P}>0.50$ \\
\hline Spatulifer maringaensis & $0.256^{*}$ & $0.005<\mathrm{P}<0.01$ & $0.765^{*}$ & $0.02<\mathrm{P}<0.05$ \\
\hline Nupelia portoriquensis & $0.106^{\mathrm{NS}}$ & $0.20<\mathrm{P}<0.50$ & $0.728^{\mathrm{NS}}$ & $0.02<\mathrm{P}<0.05$ \\
\hline
\end{tabular}

$*$ reject $\mathrm{H}_{0}$

$\mathrm{NS}=$ acept $\mathrm{H}_{0}$

TABLE 5

Values of the Mann-Whitney test $(U)$ to compare intensity of infection between males and females and the Log-likelihood test (G), to compare prevalence between males and females, of 107 specimens of Sorubim lima collected from March 1992 to February 1996 in the floodplain of the upper Paraná river, Brazil. $(\mathrm{Z}=$ value of the normal approximation of the $U$ test; $P$ = significance level.)

\begin{tabular}{|l|c|c|c|c|}
\hline \multicolumn{1}{|c|}{ Parasite } & Z & P & "G” & P \\
\hline Paramonticellia itaipuensis & $0.446^{\mathrm{NS}}$ & $\mathrm{P}>0.25$ & $0.241^{\mathrm{NS}}$ & $0.50<\mathrm{P}<0.75$ \\
\hline Spatulifer maringaensis & $2.332^{*}$ & $0.005<\mathrm{P}<0.01$ & $0.183^{\mathrm{NS}}$ & $0.50<\mathrm{P}<0.75$ \\
\hline Nupelia portoriquensis & $1.722^{*}$ & $0.025<\mathrm{P}<0.05$ & $3.043^{\mathrm{NS}}$ & $0.05<\mathrm{P}<0.10$ \\
\hline
\end{tabular}

$*$ reject $\mathrm{H}_{0}$

$\mathrm{NS}=$ acept $\mathrm{H}_{0}$

\section{DISCUSSION}

\section{Structure of infracommunity of proteocephalid cestodes}

Dominance of proteocephalids in parasite community has been detected in this research. This may have occurred owing to the feeding habit of the Sorubim lima whose feeding items include various fish which may be the intermediate hosts of these parasites. Probably due to this fact, there is a low intensity of infection by other endoparasite groups. In the fish studied only some nematodes were collected, but with very low prevalence and intensity. Nematodes were still in larval phase and, therefore, species could not be identified. The dominance of a certain species or group of parasites 
is common. However, there are many mechanisms that determine such dominance. Interference mechanisms may also occur in which certain parasite species form a hostile environment for other species or competition for a certain nutrient. Cestodes and acanthocephalans are known to absorb monosaccharides (sometimes dissaccharides) for energy metabolism. The capacity of using these nutrients favors certain parasites. Nevertheless, it should be emphasized there is still much discussion about many of these mechanisms (Holmes, 1990b).

According to Bush's importance value, Sorubim lima was parasitized by three species which are considered dominant (Paramonticellia itaipuensis, Spatulifer maringaensis and Nupelia portoriquensis) and one co-dominant species (Spasskyellina spinulifera). These and other differences registered as prevalent among species probably occurred owing to the degree of host specificity of parasite. Although $S$. maringaensis has been first described in Hemisorubim platyrhynchos (Valenciennes, 1840), the parasite seems to be more adapted to Sorubim lima, since it showed higher prevalence and average intensity. Among the other dominant species, $P$. itaiupensis was first described in Sorubim lima, but has also been recorded in $H$. platyrhynchos (Pavanelli et al., 1997). Nupelia portoriquensis is specific to Sorubim lima and has not been yet found in any other host. Spasskyellina spinulifera, classified as co-dominant, was described for Pseudoplatystoma corruscans (Agassiz, 1829). This is the first record of the species in $S$. lima.

Simpson's index showed the existence of a possible concentration to dominance among species of proteocephalids. Result may have been caused by Spatulifer maringaensis with $85.05 \%$ prevalence and average intensity of 76.06. This suggests that Sorubim lima has a complex set of species, or rather, the opposite of what happens in sea fish (Luque et al., 1996; Takemoto et al., 1996). According to Holmes (1990b), the dominion of S. maringaensis may occur because of interference mechanisms. Zavras \& Roberts (1985) noted that in high intensities of Hymenolepis diminuta inhibitors are secreted and thus DNA synthesis of species with low density is reduced. Notwithstanding, the precise function of these inhibitors is not known.

The study of similarity indexes is very important as indicators of ecological relationships among different hosts or as indicators of different populations of the same species (Holmes \& Podesta, 1968; Leong \& Holmes, 1981; Pence et al., 1983; Holmes, 1990a). With regard to environments, Sorenson's similarity index showed high similarity in parasite composition. Such similarity may be due to intercommunication between environments during the high water period.

\section{Influence of host's standard length and sex in} the infracommunity of proteocephalid cestodes Generally standard length in fish is directed related to age (Shotter, 1973). During fish ontogenetic development, various changes may occur in the behavior and in its biology, in particular, with regard to diet and physiological conditions. All these changes may have considerable influence on parasitic fauna, especially parasite species which utilize various organisms as intermediate hosts. These organisms, parasites acquired trophically, constitute the fish's diet (Takemoto et al., 1996). This is the case with proteocephalid cestodes which have larval phases in crustaceans and small forager fish (Olsen, 1977).

Results show that only the species Spatulifer maringaensis have significant positive correlation between host's standard length and intensity of parasitism. No species had significant negative correlation. Concerning $S$. maringaensis and $N$. portoriqensis, prevalence was positively and significantly correlated with standard length of hosts. Besides, no species had negative correlation. According to Hahn et al. (1997), in the floodplain of the upper Paraná river, S. lima feeds on crustaceans and fish, such as Astyanax bimaculatus (Linnaeus, 1758) and Pimelodella gracilis (Valenciennes, 1836). However, there are no studies on qualitative and quantitative variations in the feeding habit as a function of ontogenetic development. A cumulative process may be thus occurring. Same results were arrived at by Kennedy \& Hine (1969) and Scholz (1989) for proteocephalids cestodes. However, this process is more common in ectoparasites in which transmission is direct. In bigger fish in which branchial and body surfaces are greater, and thus harboring more parasites, the cumulative process is favored (Fernando \& Hanek, 1976). The process was registered by various authors who studied monogenetic infestations (Smith, 1972; Winch, 1983; Adams, 1985; 
Ramasamy et al., 1985; Fernandez et al., 1986; Janovy \& Hardin, 1987; Silan \& Maillard, 1989; Gonzalez-Lanza et al., 1991). Present research favors belief in that an increase in surface area and available space in big fish and a greater quantity of food taken by bigger fish would favor an increase in the level of parasitism.

In previous studies Takemoto \& Pavanelli (1994) found three species of proteocephalids cestodes (Travassiella avitelina Rego \& Pavanelli, 1978, Peltidocotyle rugosa Diesing, 1850 and Goezeella agostinhoi Pavanelli \& Machado do Santos, 1992) in the "jau", Paulicea luetkeni (Steindachner, 1801) in the Itaipu reservoir and in the upper Paraná river, with positive correlation between infection intensity and standard length of host. Two species (P. rugosa and G. agostinhoi) showed correlation between prevalence and standard length of hosts. Like S. lima, P. luetkeni is a carnivorous fish.

While studying the parasite fauna of the carnivorous "pintado", Pseudoplatystoma corruscans, of the floodplain of the upper Paraná river, Machado et al. (1994) found a positive correlation between prevalence and standard length of proteocephalids cestodes Nomimoscolex sudobim (Woodland, 1934) and Harriscolex kaparari (Woodland, 1935) and positive correlation between infection intensity and standard length of hosts by cestodes N. sudobim, Megathylacus travassosi (Pavanelli \& Machado dos Santos, 1991) and $H$. kaparari. It was affirmed that the "pintado" has variations in feeding habits, with main influences in this species of cestodes which have a heteroxene and extremely complex life cycle (Freze, 1965; Jarecka, 1975).

It has been found that in $P$. luetkeni and $P$. corruscans, as well as in S. lima, an increase in the size and age of fish means a significant increase in the levels of parasitism (Takemoto \& Pavanelli, 1994; Machado et al., 1994).

Although not observed in the present research work, some authors also show the occurrence of negative correlations, or rather, an increase in the host's size means a reduction in levels of parasitism (Zdzitowiecki, 1988; Oliva et al., 1990). In cases where this fact occurs, negative correlation may be verified owing to changes in the feeding habit (the fish may give up feeding on a certain item which functions as an intermediate host in the adult phase) or to the development of the immunity reaction that occurs in older fish (Adams, 1985). In their study on marine and fresh water ectoparasites other authors (Shotter, 1973; Hanek \& Fernando, 1978a,b; Fernandez, 1985; Valtonen et al., 1990; Roubal, 1990) found higher levels of parasitism in hosts with intermediate lengths. Or rather, fish acquire the parasites in their youth phase which are then eliminated in the fish's adult phase. This fact may show the development of an immunological resistance in adults.

Effects of host's sex on levels of parasitism have been studied in various endothermic vertebrates. Nevertheless, they have been also found in ectothermic hosts (Lawrence, 1970). Physiological and biological factors and behavioral differences between males and females may function to produce a small, albeit consistent, sexual trend in infection levels. Thomas (1964) has found greater intensity of parasitism in female Salmo trutta (Linnaeus, 1758). These three-year old females were more parasitized during spawning or immediately after this period.

The chief factor that may interfere in this process is the stress caused during the reproductive period since fish become more liable to be parasitized. Further, during the reproductive period behavioral changes may occur that would favor or not the acquisition of parasites.

The relationship among levels of parasitism and the host's sex was also analyzed in the floodplain by Takemoto \& Pavanelli (1994) and by Machado et al. (1994) in Paulicea luetkeni and Pseudoplatystoma corruscans respectively. Studies reported that there was no difference in levels of parasitism in male and female hosts.

In the present research two species of cestodes, Spatulifer maringaensis and Nupelia portoriquensis demonstrated significant differences in the intensity of parasites with regard to fish's sex. Intensity was greater in male hosts for these two parasite species. According to Folstad \& Karter (1992), apud Poulin (1996), high levels of testosterone may cause immunosuppression in males and make them more susceptible to parasites than in females. No difference was noted with regard to prevalence. There are, however, no studies that show behavioral or physiological differences between males and females of Sorubim lima, even though there are differences in levels of parasite infection. 
Acknowledgments - We are grateful to Dr. Amilcar Arandas Rego (Fiocruz, RJ) and Dr. Angelo Antonio Agostinho (UEM) for the critical review of the manuscript.

\section{REFERENCES}

ADAMS, A. M., 1985, Parasites on the gills of the Plains Killifish, Fundulus kansae, in the South Platte River, Nebraska. Trans. Am. Microsc. Soc., 104: 278-284.

AMATO, J. F. R., BOEGER, W. A. \& AMATO, S. B., 1991, Protocolos para laboratório - coleta e processamento de parasitos do pescado. Imprensa Universitária, Universidade Federal do Rio de Janeiro, Rio de Janeiro, 81p.

BUSH, A. O., AHO, J. M. \& KENNEDY, C. R., 1990, Ecological versus phylogenetic determinants of helminth parasite community richness. Evolutionary Ecology, 4: 120.

BUSH, A. O., LAFFERTY, K. D., LOTZ, J. M. \& SHOSTAK, A. W., 1997, Parasitology meets ecology on its own terms: Margolis et al., revisited. J. Parasitol., 83(4): 575-583.

FERNANDEZ, B. J., 1985, Estudio parasitológico de Merluccius australis (Hutton, 1872) (Pisces: Merluccidae): aspectos sistemáticos, estadisticos y zoogeograficos. Bol. Soc. Biol. Concepción, Chile, 56: 31-41.

FERNANDEZ, J. C., VILLALBA, C. S. \& ALVIÑA, A., 1986, Parasitos del Pejegallo, Callorhynchus callorhynchus (L.), en Chile: aspectos biológicos y sistemáticos. Biol. Pesq., 15: 63-73.

FERNANDO, C. H. \& HANEK, C., 1976, Gills. In: C. R. Kennedy (ed.), Ecological aspects of Parasitology. NorthHolland Publishing Company, Amsterdam, pp. 209-226.

FREZE, V. I., 1965, Essentials of cestodology. Volume 5. Proteocephalata, in fish amphibians and reptiles. English translation 1969. Israel Program of Scientific Translations, Jerusalém, 597p.

GONZALEZ-LANZA, C., ALVAREZ-PELLITERO, P. \& SITJA-BOBADILLA, A., 1991, Diplectanidae (Monogenea) infestations of sea bass, Dicentrarchus labrax (L.), from the Spanish Mediterranean area. Histopatology and population dynamics under culture conditions. Parasitol. Res., 77: 307-314.

HAHN, N. S., ANDRIAN, I. F., FUGI, R. \& ALMEIDA, V. L. L., 1997, Ecologia trófica. In: A. E. A. M. Vazzoler, A. A. Agostinho \& N. S. Hahn (eds.), A planície de inundação do alto rio Paraná: aspectos físicos, biológicos e socioeconômicos. EDUEM, Maringá, pp. 209-228.

HANEK, G. \& FERNANDO, C. H., 1978a, The role of season, habitat, host age, and sex on gill parasites of Lepomis gibbosus (L.). Can. J. Zool., 56: 1247-1250.

HANEK, G. \& FERNANDO, C. H., 1978b, The role of season, habitat, host age, and sex on gill parasites of Ambloplites rupestris (Raf.). Can. J. Zool., 56: 1251-1253.

HOLMES, J. C., 1990a, Helminth communities in marine fishes. In: G. Esch, A. O. Bush \& J. Aho (eds.), Parasite communities: patterns and processes Chapman and Hall, New York, pp. 101-130.
HOLMES, J. C., 1990b, Competition, contacts, and other factors restricting niches of parasitic helminths. Ann. Parasitol. Hum. Comp., 65: 69-72.

HOLMES, J. C. \& PODESTA, P. W., 1968, The helminths of wolves and coyotes from the forested regions of Alberta. Can. J. Zool., 46: 1193-1204.

JANOVY Jr., J. \& HARDIN, E. L., 1987, Populations dynamics of the parasites in Fundulus zebrinus in the Platte river of Nebraska. J. Parasitol., 73(4): 689-696.

JARECKA, L., 1975, Ontogeny and evolution of cestodes. Acta Parasitol. Pol., 23(4): 93-114.

KENNEDY, C. R. \& HINE, P. M., 1969, Population biology of the cestode Proteocephalus torulosus (Batsch) in Dace Leuciscus leuciscus (L.) of the river Avon. J. Fish Biol., 1: 209-219.

LAWRENCE, J. L., 1970, Effects of season, host age, and sex on endohelminths of Catostomus commersoni. J. Parasitol., 56(3): 567-571.

LEONG, T. S. \& HOLMES, J. C., 1981, Communities of metazoan parasites in open water fishes of Cold Lake, A1berta. J. Fish Biol., 18: 693-713.

LUQUE, J. L., AMATO, J. F. R. \& TAKEMOTO, R. M., 1996, Comparative analysis of the communities of Metazoan parasites of Orthopristis ruber and Haemulon steindachneri (Osteichthyes: Haemulidae) from the Southeastern Brazilian littoral: I. Structure and influence of the size and sex of hosts. Rev. Brasil. Biol., 56(2): 279-292.

MACHADO, M. H., PAVANELLI, G. C. \& TAKEMOTO, R. M., 1994, Influence of host's sex and size on endoparasitic infrapopulations of Pseudoplatystoma corruscans and Schizodon borelli (Osteichthyes) of the high Paraná River, Brazil. Rev. Brasil. Parasitol. Vet., 3(2): 143-148.

MACHADO, M. H., PAVANELLI, G. C. \& TAKEMOTO, R. M., 1995, Influence of the type of environment and of the hydrological level variation in endoparasitic infrapopulations of Pseudoplatystoma corruscans and Schizodon borelli (Osteichthyes) of the high Paraná River, Brazil. Rev. Brasil. de Zool., 12(4): 961-976.

MACHADO, M. H., PAVANELLI, G. C. \& TAKEMOTO, R. M., 1996, Structure and diversity of endoparasitic infracommunities and the trophic level of Pseudoplatystoma corruscans and Schizodon borelli (Osteichthyes) of the high Paraná River. Mem. Inst. Oswaldo Cruz, 91(4): 441448

MARGOLIS, L., ESCH, G. W., HOLMES, J. C., KURIS, A. M. \& SCHAD, G. A., 1982, The use of ecological terms in Parasitology (report of an ad hoc committee of the American Society of Parasitologists). J. Parasitol., 68 (4): 131-133.

NERAASEN, T. G. \& HOLMES, J. C., 1975, The circulation of cestodes among three species of geese nesting on the Anderson River Delta, Canada. Acta Parasitol. Pol., 23: $277-289$.

OLIVA, M., LUQUE, J. L. \& IANNACONE, J. A., 1990, The metazoan parasites of Stellifer minor (Tschudi, 1844): an ecological approach. Mem. Inst. Oswaldo Cruz, 85(3): 271-274. 
OLSEN, O. W., 1977, Parasitologia animal. II Platelmintos, Acantocéfalos y Nematelmintos. Aedos, Barcelona, 719p.

PAVANELLI, G. C., MACHADO, M. H. \& TAKEMOTO, R. M., 1997, Fauna helmíntica de peixes do rio Paraná, região de Porto Rico, PR. In: A. E. A. M. Vazzoler, A. A. Agostinho \& N. S. Hahn (eds.), A planície de inundação do alto rio Paraná: aspectos físicos, biológicos e socioeconômicos. EDUEM, Maringá, pp. 301-323.

PENCE, D. B., CRUM, J. M. \& CONTI, J. A., 1983, Ecological analyses of helminth populations in the Black bear, Ursus americanus, from North America. J. Parasitol., 69(5): 933-950.

POULIN, R., 1996, Sexual inequalities in helminth infections: a cost of being a male? Am. Nat., 147(2): 287-295

RAMASAMY, P., RAMALINGAM, K., HANNA, R. E. B. \& HALTON, D. W., 1985, Microhabitats of gill parasites (Monogenea and Copepoda) of teleosts (Scomberoides spp.). Int. J. Parasitol., 15(4): 385-397.

ROUBAL, F. R., 1990, Seasonal changes in ectoparasite infection of juvenile yellowfin bream, Acanthopagrus australis (Günther) (Pisces: Sparidae), from a small estuary in Northern New South Wales. Aust. J. Mar. Freshwater Res., 41: 411-427.

SCHOLZ, T., 1989, On the ecology of the tapeworn Proteocephalus torulosus (Batsch, 1786) (Cestoda: Proteocephalidea) in chub (Leuciscus cephalus (L.)) from the river Rokytná, Czechoslovakia. Helminthologia, 26: 275-287.

SHOTTER, R. A., 1973, Changes in the parasite fauna of whiting Odontogadus merlangus L. with age and sex of host, season, and from different areas in the vicinity of the Isle of Man. J. Fish Biol., 5: 559-573.

SIEGEL, S., 1975, Estatística Não Paramétrica (Para Ciências do Comportamento). McGraw-Hill do Brasil, São Paulo, 350p.

SILAN, P. \& MAILLARD, C., 1989, Biology of Serranicotyle labracis, ectoparasite of Dicentrarchus labrax (Teleostei): contribution to the study of its populations. Mar. Biol., 103: 481-487.

SMITH, J. W., 1972, The occurrence of Diclidophora esmarkii (Monogenea) on Norway Pout, Trisopterus esmarkii (Nilsson, 1855), in the Northern Sea and to the North and West of Scotland. J. Cons. Int. l'Explor. Mer, 34: 256261 .
STONE, J. E. \& PENCE, D. B., 1978, Ecology of helminth parasitism in the bobcat from West Texas. J. Parasitol., 64(2): 295-302.

TAKEMOTO, R. M., AMATO, J. F. R. \& LUQUE, J. L., 1996, Comparative analysis of the metazoan parasite communities of leatherjackets, Oligoplites palometa, $O$. saurus, and $O$. saliens (Osteichthyes: Carangidae) from Sepetiba Bay, Rio de Janeiro, Brazil. Rev. Brasil. Biol., 56(4): 639-650.

TAKEMOTO, R. M. \& PAVANELLI, G. C., 1994, Ecological aspects of Proteocephalidean cestodes parasites of Paulicea luetkeni (Steindachner) (Osteichthyes: Pimelodidae) from the Paraná river, Paraná, Brazil. Rev. UNIMAR, 16 (Supl. 3): 17-26.

THOMAS, J. D., 1964, A comparison between the helminth burdens of male and female brown trout, Salmo trutta (L.) from a natural population in River Teify, West Wales. Parasitology, 54: 263-272.

THUL, J. E., FORRESTER, D. J. \& ABERCROMBIE, C. L., 1985, Ecology of parasitic helminths of Wood Ducks, Aix sponsa, in the Atlantic Flyway. Proc. Helminthol. Soc. Wash., 52(2): 297-310.

VALTONEN, E. T., PROST, M. \& RAHKONEN, R., 1990, Seasonality of two gill monogeneans from two freshwater fish from an oligotrophic lake in northeast Finland. Int. J. Parasitol., 20(1): 101-107.

WINCH, J., 1983, The biology of Atrispinum labracis n. comb. (Monogenea) on the gills of the bass Dicentrarchus labrax. J. Mar. Biol. Assoc. UK, 63: 915-927.

YANEZ, D. M. \& CANARIS, A. C., 1988, Metazoan parasite community composition and structure of Migrating Wilson's Phalarope, Steganopus tricolor Viellot, 1819 (Aves), from El Passo county, Texas. J. Parasitol., 74: 754-762.

ZAR, J. H., 1996, Biostatistical Analysis. $3^{\text {rd }}$ ed., PrenticeHall, Inc., Upper Saddle River, New Jersey, USA, 662p.

ZAVRAS, E. T. \& ROBERTS, L. S., 1985, Developmental physiology of cestodes: cyclic nucleotides and the identity of putative crowding factors in Hymenolepis diminuta. J. Parasitol., 71: 96-105.

ZDZITOWIECKI, K., 1988, Occurrence of digenetic trematodes in fishes of South Shetlands (Antarctic). Acta Parasitol. Pol., 33: 155-167. 